\title{
Symbiosis
}

December 2012, Volume 58, Issue 1-3, pp 233-244

http://dx.doi.org/10.1007/s13199-012-0195-x

\section{Multiple microalgal partners in symbiosis with the acantharian Acanthochiasma sp. (Radiolaria)}

\author{
Johan Decelle ${ }^{1,2,{ }^{*}}$, Raffaele Siano ${ }^{3}$, Ian Probert ${ }^{4}$, Camille Poirier ${ }^{1,2}$, Fabrice Not ${ }^{1,2}$ \\ 1 UPMC University Paris 06, UMR 7144, Station Biologique, 29680, Roscoff, France \\ ${ }^{2}$ CNRS, UMR 7144, Station Biologique, 29680, Roscoff, France \\ ${ }^{3}$ IFREMER, Centre de Brest, DYNECO/Pelagos, BP 70 29280, Plouzané, France \\ ${ }^{4}$ UPMC University Paris 06, FR 2424, Station Biologique, 29680, Roscoff, France \\ *: Corresponding author : Johan Decelle, decelle@sb-roscoff.fr
}

\begin{abstract}
:
Acantharia (Radiolaria) are widespread and abundant heterotrophic marine protists, some of which can host endosymbiotic eukaryotic microalgae. Although this photosymbiotic association was first described at the end of the 19th century, the diversity of the symbiotic microalgae remains poorly characterized. Here, we examined the identity of the microalgae associated with the acantharian species Acanthochiasma sp. by sequencing partial $18 \mathrm{~S}$ and internal transcribed spacer (ITS) ribosomal DNA genes from cultured symbionts and directly from isolated holobiont specimens. Single Acanthochiasma cells contained multiple symbiotic partners, including distantly related dinoflagellates (Heterocapsa sp., Pelagodinium sp., Azadinium sp. and Scrippsiella sp.) as well as a haptophyte (Chrysochromulina $s p$.). This original association of multiple symbiotic microalgae within a single host cell raises questions about the specificity and functioning of the relationship. These microalgae exhibit the common ecological feature of being abundant and widely distributed in coastal and oceanic waters, some occasionally forming extensive blooms. Some of the microalgal genera found in association with Acanthochiasma (i.e. Pelagodinium and Chrysochromulina) are known to occur in symbiosis with other heterotrophic protists such as Foraminifera and other Radiolaria, whereas Heterocapsa, Scrippsiella and Azadinium have never previously been reported to be involved in putative symbiotic relationships. The unusual association unveiled in this study contributes to our understanding of the ecological and evolutionary significance of photosymbiosis in Acantharia and also provides new insights into the nature of such partnerships in the planktonic realm.
\end{abstract}

Keywords: Photosymbiosis ; Radiolaria ; Acantharia ; Protists ; Microalgae ; Plankton 


\section{Introduction}

Symbiosis defines a mode of life whereby distantly related organisms live in close association with each other over multiple generations (de Bary, 1878). Symbiotic relationships encompass a wide range of interaction strategies and mechanisms, from parasitism to mutualism. In the $19^{\text {th }}$ century, the first investigations on the symbiosis were carried out on lichens, Cnidaria and Radiolaria. Originally considered parasitic (Cienkowsky 1871), Brandt (1881) used physiological experiments to demonstrate that the symbiotic microalgae of these host types are in fact independent entities that are highly beneficial for the nutrition of the hosts, and formally described the symbionts as Zooxanthella nutricula. Heterotroph-phototroph symbioses (photosymbioses) in reef-dwelling invertebrates have since been extensively studied and are typically regarded as mutualistic relationships, with the symbiont providing photosynthetically derived products to the host, which in turn maintains a sheltered and nutrient-rich environment for the symbiont (Muscatine et al. 1984; Yellowlees et al. 2008). By comparison, photosymbiotic relationships between planktonic organisms have received little attention despite their abundance and widespread distribution in the photic zone of the world ocean (Stoecker 2009). Certain large heterotrophic unicellular eukaryotes, such as Foraminifera and Radiolaria (Acantharia and Polycystinea), are known to harbor microalgal symbionts, especially in oligotrophic oceanic waters where they significantly contribute to primary production (Michaels 1988). In these cases, the symbiotic association is apparently obligatory for the hosts, and in most cases they must acquire their microalgal symbionts from the surrounding environment (i.e. horizontal transmission) at each generation. Microalgae involved in symbiosis are typically considered to be specialized for a symbiotic life-style, but the degree of benefit and the dependence on symbiosis for their survival is less clear (Douglas and Smith 1989; Wooldrige 2010).

The diversity of symbiotic microalgae in the planktonic realm has been poorly characterized, essentially due to the alteration or loss of diagnostic morphological features of the symbiotic cells in hospite (e.g. loss of flagella, scales, cell wall, etc.) and the low success rate of culture isolation. In such cases, DNA-based techniques using molecular markers such as the $18 \mathrm{~S}$ rDNA gene have been proven to be an effective means of obtaining good taxonomic resolution. Molecular studies have demonstrated that the colloquial name "zooxanthellae" (from Zooxanthella nutricula) in fact entails a broad diversity of microalgal lineages. In contrast to most invertebrates in benthic-coastal ecosystems that exclusively host the dinoflagellate genus Symbiodinium (order Suessiales), Radiolaria do not seem to be specialized for a single group of microalgae, but can live in symbiosis with representatives from distinct eukaryotic lineages, such as haptophytes, dinoflagellates (order Peridiniales) and prasinophytes (Decelle et al. submitted; Gast and Caron 1996, 2001). Ultrastructural and molecular analyses have shown that these three different lineages can even occur as symbionts in a single polycystine genus, Spongodrymus (Anderson 1983). The cyanobacteria Synechococcus sp. and Prochloroccocus sp. can also be photosymbionts of radiolarians, as described in the polycystine Dictyocoryne sp. (Foster et al. 2006a,b; Yuasa 2012). Thus, Radiolaria-microalga photosymbiotic partnerships seem to be 

taxonomic scales, preventing an accurate understanding of specificity patterns.

The Acantharia are a monophyletic group of radiolarians characterized by their mineral endoskeleton composed of celestite (strontium sulfate). Acantharia generally outnumber their Polycystinea and Foraminifera counterparts in coastal and open ocean waters (Michaels 1995). A recent phylogenetic analysis of these uncultivated protists described nine molecular clades (I to III and A to F) and highlighted the need for a revision of the taxonomic framework that dates back to the pioneering works of Haeckel (1888) and Schewiakoff (1926) (Decelle et al. 2012). Acantharia are known to be active predators using their axopods to capture a wide range of small protists (e.g. ciliates) that are rapidly digested in the outer part of the cytoplasm, called the ectoplasm (Swanberg and Caron 1991). Like other radiolarians, some species also have an indirect photosynthetic capacity by hosting symbiotic microalgal cells in their endoplasm. In the Equatorial Pacific and Gulf of Mexico, about $40 \%$ of Acantharia were found to bear algal symbionts, contributing up to $80 \%$ of acantharian biomass (Stoecker, 1996), and in the Sargasso Sea and Pacific Ocean, the symbiotic forms can occasionally account for up to $20 \%$ of the total primary production in surface waters (Michaels 1988). Three decades ago, in hospite ultrastructural investigations described the photosymbionts of Acantharia as being either haptophytes or dinoflagellates (Febvre and Febvre-Chevalier 1979; Hollande and Carré 1974), but there have since been few attempts to provide a more precise taxonomic assignation of both partners. A molecular study recently demonstrated that Acantharia from clades E and F (orders Symphiacanthida and Arthracanthida) live in symbiosis worldwide with the haptophyte genus Phaeocystis, a phytoplankton taxon that is very abundant and widespread in its free-living condition (Decelle et al. submitted). Acanthochiasma sp. (order Holacanthida) from the earlier diverging clade B is also known to harbor intracellular microalgae (Schewiakoff 1926).

The objective of this study was to genetically identify the microalgal cells associated with the acantharian species Acanthochiasma sp.. To do so, we analyzed symbiont $18 \mathrm{~S}$ and internal transcribed spacer (ITS) ribosomal DNA gene sequences directly from the holobiont (host and microalgae) and from clonal cultures of microalgae obtained after microdissection and singlecell isolation. Identification of these symbiotic microalgae will contribute to our understanding of the evolution, functioning and ecology of photosymbiosis in Acantharia. 


\section{Materials and Methods}

\section{Sample collection}

Twelve cells of the acantharian species Acanthochiasma sp. were collected in the Mediterranean Sea (Villefranche-sur-Mer; 4340.552 N, $7^{\circ} 18.447$ E) in September 2010 and 2011 by gently towing a plankton net $(150 \mu \mathrm{m}$ mesh size) at the subsurface. Morphological identification was performed based on the diagnostic features described in the acantharian taxonomic framework of Schewiakoff (1926). Cells were immediately isolated from the raw plankton sample using glass micropipettes under inverted microscopy, transferred into $0.2-\mu \mathrm{m}$-filtered seawater, and let to incubate for several hours to allow self-cleaning (debris and particles are removed and prey digested). After incubation, each acantharian cell was rinsed several times in 0.2 - $\mu \mathrm{m}$-filtered seawater, and observed through an epifluorescence microscope to check the red chlorophyll autofluorescence of the intracellular microalgae. In order to investigate the identity of these microalgae, molecular analyses were performed either on cultures of microalgae isolated after microdissection of the host or directly on the holobiont cell.

\section{Culture isolation and molecular analysis}

Acanthochiasma sp. cells were microdissected under an inverted microscope and the intracellular microalgae subsequently isolated by micropipette. Individual symbiont cells were transferred into a single well of a multi-well plate containing $\mathrm{K} / 10(-\mathrm{Si},+\mathrm{Ni})$ medium (Keller et al. 1987) and maintained at $19^{\circ} \mathrm{C}$ with illumination provided by daylight neon tubes at an intensity of ca. 30 $\mu$ Einsteins. $\mathrm{m}^{-2} . \mathrm{s}^{-1}$ and a photoperiod (L:D) of 14:10 hours. Successful cultures were harvested during exponential growth phase and concentrated by centrifugation. Total nucleic acids were extracted using the Nucleospin ${ }^{\circledR}$ RNA II kit (Macherey-Nagel, Hoerdt, France) and quantified using a Nanodrop ND-1000 Spectrophotometer (Labtech International, France). The eukaryotespecific primers $63 \mathrm{~F} / 1818 \mathrm{R}$ were used to amplify the $18 \mathrm{~S}$ rDNA of the different cultures (information on primers is detailed in Online Ressource 1). In addition, the specific primers ITSCer/D1R-R were used to amplify the partial Internal Transcribed Spacer (ITS) of the dinoflagellate cultures. Polymerase Chain Reactions (PCRs) were performed using Phusion highfidelity DNA polymerase (Finnzymes) in a $25-\mu 1$ reaction volume as follows: an initial denaturation step at $98{ }^{\circ} \mathrm{C}$ for $30 \mathrm{sec}$, followed by 35 cycles at $98{ }^{\circ} \mathrm{C}$ for $10 \mathrm{sec}$, at $50{ }^{\circ} \mathrm{C}(18 \mathrm{~S}$ rDNA) or at $53^{\circ} \mathrm{C}$ (ITS) for $30 \mathrm{sec}$, and at $72{ }^{\circ} \mathrm{C}$ for $30 \mathrm{sec}$, with a final elongation step of 10 minutes at $72{ }^{\circ} \mathrm{C}$. PCR products were then purified by EXOSAP-IT (GE Healthcare BioSciences Corp.) and bidirectionally sequenced using the ABI-PRISM Big Dye Terminator Cycle Sequencing Kit (Applied Biosystems). Note that the PCR parameters and the associated steps were similar throughout this study, except for the annealing temperature that changed according to the primers (Online Ressource 1).

\section{Molecular analysis on the holobiont cell}

Each holobiont isolated was photographed prior to transfer into an extraction buffer (GITC, de Vargas 2002). DNA extraction was performed as explained in Decelle et al. (2012). Molecular 
identification of the host Acanthochiasma sp. was first performed in order to check whether it entails cryptic species and thus to assess the specificity of the symbiosis. To do so, the $28 \mathrm{~S}$ rDNA (D1/D2 domains) and the ITS (including the ITS1, 5,8S and the ITS2) of different host individuals were PCR amplified with Radiolaria-specific primers (Online Ressource 1). Since the symbiotic microalgae of Acantharia have previously been described as belonging to either haptophytes or dinoflagellates (Febvre and Febvre-Chevalier 1979; Hollande and Carré 1974), specific primers for these two lineages were selected to specifically amplify their partial $18 \mathrm{~S}$ rDNA and ITS ribosomal genes from each holobiont cell. For the 18S rDNA genes of haptophytes and dinoflagellates, the specific primers Prym429F/Prym02R and DIN464F/S69 were used respectively (Online Ressource 1). The dinoflagellate-specific ITS primers mentioned above (ITS-Cer/D1R-R) were also used for the holobiont PCR. A nested PCR was sometimes necessary to obtain a detectable quantity of amplicons, especially for the 18S rDNA genes of the haptophytes. The first amplification was undertaken with the general primers $63 \mathrm{~F}$ and $1818 \mathrm{R}(25$ cycles), and $1 \mu 1$ of $10 \mathrm{X}$ diluted amplicon was used for re-amplification with the internal specific primers of haptophytes or dinoflagellates. Sequences obtained in this study were deposited in GenBank under accession numbers XXXX to XXXX.

\section{Phylogenetic analyses}

Four distinct matrices (18S rDNA dinoflagellates, ITS dinoflagellate Peridiniales, ITS dinoflagellate Suessiales and 18S rDNA haptophytes) were built from the microalgal sequences obtained in this study and additional sequences retrieved from GenBank. Separate analyses on the ITS of Peridiniales and the ITS of Suessiales were required to improve the alignment. The four matrices were aligned with the program MUSCLE, implemented in Seaview v.4.0 (Gouy et al. 2010), and the optimal model of evolution was determined under the AIC, AICc and BIC criteria using MEGA v5.05 (Tamura et al. 2011). Phylogenetic reconstructions were performed using Maximum Likelihood (ML) and statistical support assessed by performing 100 bootstrap replicates with MEGA v5.05. 


\section{Results}

\section{Molecular identification of host cells}

We collected twelve Acanthochiasma sp. host cells (Fig. 1), and sequenced partial 28S rDNA ( $\sim 700 \mathrm{bp}$ ) for eight of these, and partial ITS ribosomal genes ( 930 bp) for three. For both of these phylogenetic markers, the sequences obtained were strictly identical (Table 1). Sharing the same genetic footprint, all of the host specimens collected in this study can reasonably be considered to belong to a single taxonomic entity. Note that the acantharian specimens from clade B in Decelle et al (2012) were erroneously identified as Acanthocyrta haeckeli but correspond in fact to Acanthochiasma sp.

\section{Molecular identification of the intracellular microalgae}

We retrieved sequences of dinoflagellates from both cultures and holobiont cells, whereas haptophyte sequences were only obtained from holobiont cells (Table 1).

Dinoflagellates: The twelve 18S rDNA sequences recovered from nine host individuals belonged to the dinoflagellate orders Peridiniales and Suessiales (Fig. 2). In the former, five sequences fell into a monophyletic group representing the genus Heterocapsa (bootstrap values $(B V)=56 \%$ ), and three of these (Vil 39, Vil 64 and Acanth 23) grouped more specifically with reference sequences of Heterocapsa rotundata (BV $=94 \%$ ), sharing up to $99 \%$ identity. In addition, two symbiont sequences, AC 24-3 and PEC 18, were related to the genera Scrippsiella $(\mathrm{BV}=100 \%)$ and Azadinium $(\mathrm{BV}=100 \%)$, respectively. None of the sequences retrieved from Acanthochiasma grouped with the Peridiniales clade named "Scrippsiella nutricula", which encompasses several sequences of symbiotic microalgae living within the jellyfish Vellela vellela and other Radiolaria (Collodaria and Spumellaria).

Five 18S rDNA sequences (AC 24, AC 24-2, Vil 60, AR1 and AR2) from four distinct host cells fell into the order Suessiales, and were closely related to the reference sequence of Pelagodinium béii (99\% identity), previously known as Gymnodinium béii (Siano et al. 2010; Spero 1987). The sequences of $P$. béii formed a monophyletic group (BV $=74 \%)$ and included the sequence AC 24-0. The sequences AC 24-2, Vil 60, AR1 and AR2 appeared to constitute a distinct subgroup that branched with the $P$. béii group with low support $(\mathrm{BV}<50 \%)$. Microalgal sequences from the same host cell were sometimes genetically different (e.g. AC 24), indicating that a single host cell can live with different genotypes or strains of $P$. béii. Remarkably, the host individual AC 24 simultaneously possessed microalgae of the genera Scrippsiella, Pelagodinium and Heterocapsa (Table 1).

The 18S rDNA phylogenetic tree of dinoflagellates was weakly resolved as previously recognized (Saldarriaga et al. 2004). In order to confirm and improve the phylogenetic placement of the dinoflagellates associated with Acanthochiasma sp., we amplified and sequenced the more resolutive locus ITS that has been shown to be a good marker for dinoflagellate phylogeny at the species level (LaJeunesse 2001; Stern et al. 2012). Phylogenetic analyses were performed separately for the orders Suessiales and Peridiniales. 
ITS of Peridiniales: We obtained four ITS sequences from the Peridiniales identified with the $18 \mathrm{~S}$ rDNA gene (Fig. 3). The sequence AC 24-1 branched within a clade including two sequences of the species Heterocapsa pygmaea and one sequence of $H$. triquetra $(\mathrm{BV}=100 \%)$. The sequence Vil 39, which was very close to $H$. rotundata according to the $18 \mathrm{~S}$ rDNA phylogeny, was located in a clade between an undescribed Heterocapsa taxon and several sequences of $H$. arctica $(\mathrm{BV}=88 \%)$. Note that the ITS sequence of $H$. rotundata is not available in public databases. The phylogenetic placement of PEC 18 and AC 24-3 was consistent with that obtained with the $18 \mathrm{~S}$ rDNA gene, being included in the genera Azadinium sp. (BV=100\%) and Scrippsiella sp. $(\mathrm{BV}=83 \%)$, respectively.

ITS of Suessiales: The phylogenetic tree constructed with the ITS rDNA marker confirmed the close affiliation of the Suessiales symbionts to Pelagodinium béii (Fig. 4). This fast-evolving gene resolves four sub-clades within Pelagodinium (P1a, P1b and P2a, P2b) that were defined by Shaked and de Vargas (2006). The sequence AC 24-0 clustered with sub-clade P1b with relatively high support $(\mathrm{BV}=85 \%)$. The ITS sequences AC 24-2 and AR1 that formed a distinct sub-group as in the $18 \mathrm{~S}$ rDNA phylogeny, were included with stronger support in the monophyletic $P$. béii group $(\mathrm{BV}=64 \%)$, with no clear affinity with sub-clades $\mathrm{P} 1$ and $\mathrm{P} 2(\mathrm{BV}=$ $51 \%$ ). PCR amplifications of ITS from Vil 60 and AR2 were not successful, but it can reasonably be supposed that their sequences would branch with AC24-2 and AR1, as in the 18S rDNA phylogeny (Fig. 2).

\section{Haptophytes}

Five 18S rDNA sequences from five Acanthochiasma sp. cells were related to the haptophytes, and more specifically to the order Prymnesiales (Fig. 5). The phylogenetic reconstruction indicated that the five sequences grouped within the well-supported clade B2 $(\mathrm{BV}=100 \%)$, which corresponds to the core Chrysochromulina species (Edvardsen et al. 2011). While four sequences grouped together (Vil 20, PEC 14, Vil 51 and Vil 64), Vil 45 appeared to belong to another sub-clade. Prymnesiales clade B2 also includes three sequences (named symbiont of Foraminifera 1, 3 and 4) that correspond to microalgae that were found in symbiosis with planktonic Foraminifera (Gast and Caron 2001). 


\section{Discussion}

\section{Prey or true endosymbiotic microalgae?}

We unveiled an unexpected diversity of microalgae, including the haptophyte Chrysochromulina and the dinoflagellate genera Pelagodinium (Suessiales) and Heterocapsa, Scrippsiella and Azadinium (Peridiniales), closely associated with a single host species of Acantharia. The possibility that these microalgae correspond to prey cells ingested by Acanthochiasma prior to collection cannot be ruled out. However, several lines of evidence argue in favor of the endosymbiotic nature of the microalgae identified. Firstly, light and epifluorescence microscopy observations revealed that the microalgae were located in the host endoplasm (Fig. 1), which in non-symbiotic acantharians is typically devoid of prey particles. In addition, Acantharia have been observed to digest their prey extremely rapidly (within minutes) in the ectoplasm where enzyme-containing vacuoles are released (Schewiakoff 1926; our observations). With this in mind, we paid particular attention in our sampling strategy to maintaining the acantharian cells for several hours in $0.2 \mu \mathrm{m}$-filtered seawater before rinsing, isolation and microdissection. With this procedure, we were able to obtain microalgal sequences from holobiont cells and free-living cultures of intracellular microalgae isolated. Another line of evidence resides in the fact that the host specimens studied (12 in total) were sampled in consecutive years but exhibited common microalgal taxa, indicating a degree of specificity in the relationship (Table 1). All together, this suggests that there is an intimate and long-lasting relationship between the microalgae and the acantharian species Acanthochiasma sp. Finally, some of the sequences obtained in this study were closely related to microalgae that have already been described in symbiosis with Foraminifera and other Radiolaria. The dinoflagellate $P$. béii that we found associated with Acanthochiasma sp. is known to live in symbiosis worldwide with different species of planktonic Foraminifera (Orbulina universa, Globigerinoides ruber, G. sacculifer and G. conglobatus, Gast and Caron 2001; Shacked and de Vargas 2006). Likewise, members of the haptophyte order Prymnesiales have already been found living as permanent endosymbionts not only in Radiolaria (Spongodrymus sp., Anderson et al. 1983; Gast and Caron 2001), but also in planktonic Foraminifera. More particularly, the Chrysochromulina species from clade B2 were described intracellularly in the Foraminifera species Globigerinella siphonifera (Gast and Caron 2001; Faber et al. 1988), where the microalgal symbionts reside along the spines in the endoplasmic rhizopodial network that can be extended out of the shell during the day. To our knowledge, the dinoflagellate genera Heterocapsa, Scrippsiella and Azadinium from Peridiniales have never previously been reported to be involved in symbiotic relationships. They are very likely not parasites of Acanthochiasma sp. since they do not belong to known groups of heterotrophic radiolarian parasites, such as the alveolates MALV I and MALV II (Bråt et al. 2012; Guillou et al. 2008). In addition, the proportion of infected host is generally about $1-10 \%$ (Siano et al. 2011), which is not reflecting the much higher prevalence of these three genera found in Acanthochiasma. Overall, the weight of evidence indicates that the microalgal sequences retrieved correspond to photosymbionts hosted within the endoplasm of Acanthochiasma sp., but the mechanisms underlying the relationships remains to be elucidated. 


\section{Multiple microalgal partners}

A combination of different techniques allowed us to identify microalgae of different sizes and shapes (Fig. 1) belonging to highly distant lineages, not only in a single acantharian species, but also within a single host cell (e.g. Vil 64, PEC 14, AC 24; Table 1). Occurrences of multiple symbiont taxa within a single host are considered to be rare because antagonistic interactions, such as competition for space and resources, can emerge between symbionts, and may threaten host fitness and the stability of the relationship (Douglas 1998; Franck 1996). Around 11\% of cells from populations of planktonic Foraminifera have been found to simultaneously harbor different $P$. béii genotypes (Shaked and de Vargas 2006). Some benthic foraminiferal cells can occasionally live with two or three species of endosymbiotic diatoms (Lee and Coreira, 2005). Corals, especially scleractinian species, and giant clams (Tridacna sp.) are commonly found with a heterogeneous assemblage of Symbiodinium sp., comprising up to four different genotypes (Baker and Romanski 2007; Carlos et al. 2000). Compared to these cases, Acanthochiasma is remarkable in that it associates with a much more diverse spectrum of photosynthetic partners, including several distantly related dinoflagellates as well as a haptophyte. In contrast, Acantharia from the more recently diverging clades $\mathrm{E}$ and $\mathrm{F}$ have established an exclusive symbiotic relationship with members of the haptophyte genus Phaeocystis, irrespective of host species and geographic location (Decelle et al. submitted). Given the relatively distant and more basal position of Acanthochiasma sp. within acantharian phylogeny (clade B, Decelle et al. 2012), we conclude that the multiple-partner photosymbiosis described here was established independently and before that of Acantharia from clades $\mathrm{E}$ and $\mathrm{F}$, and that it represents a relatively primitive mode of symbiosis that is not specialized on a single photosynthetic partner. In this context, it is interesting to note that the skeleton organization is less complex in Acanthochiasma (simple long spicules), and that known extant diversity within the Acanthochiasma lineage is extremely low compared with that within the monophyletic lineage of Acantharia (clades E and F) that form more specific relationships with Phaeocystis.

The two approaches adopted in this study, single-holobiont PCR and culturing, did not systematically recover the same microalgal sequences in all host cells (Table 1). This could be due to limitations in single-holobiont PCR inherent to the low number of intracellular microalgae and the variable abundance of symbiont taxa within each host. In addition, the success rate for phytoplankton cultures strongly depends on the taxa isolated and the choice of medium used. For instance, Chrysochromulina species from clade B2 are known to be difficult to grow in culture (Liu et al. 2009), and this may explain why we only obtained sequences of this taxon from holobionts. Nevertheless, combining the two approaches appeared to be a valuable strategy for identification of photosymbionts from uncultivable and unicellular host.

\section{Insights into planktonic photosymbiosis}

In coastal benthic ecosystems, the dinoflagellate Symbiodinium (Suessiales) is a common photosymbiont of marine invertebrates and protists, such as sponges, cnidarians, mollusks and 


\section{Acknowledgments}

We thank the LOV in Villefranche-sur-Mer for providing sampling facilities and Morgan Perennou and Gwen Tanguy from the GENOMER platform at the Station Biologique de Roscoff. We are grateful to the Project "Bibliothèque du Vivant" for sequencing. This research was supported by the Region Bretagne (DIPHOPE 044763) and the program JST-CNRS. 


\section{References}

Anderson OR (1983) Radiolaria. Springer-Verlag, New York

Annenkova NV, Lavrov DV, Belikov SI (2011) Dinoflagellates associated with freshwater sponges from the ancient Lake Baikal. Protist 162:22-236

Baker AC, Romanski AM (2007) Multiple symbiotic partnerships are common in scleractinian corals, but not in octocorals: Comment on Goulet (2006). Mar Ecol Prog Ser 335:237-242

Banaszak AT, Iglesias-Prieto R, Trench RK (1993) Scrippsiella velellae sp. nov. (Peridiniales) and Gloeodinium viscum sp. nov (Phytodiniales), dinoflagellate symbionts of hydrozoans (Cnidaria). J Phycol 29:517-528

Brandt K (1881) Ueber das Zusammenleben von Thieren und Algen. Verh Physiol Ges Berlin 1881(1882):22-26

Bråt J et al (2012) Radiolaria Associated with Large Diversity of Marine Alveolates. Protist 163:767-777

Carlos AA, Baillie BK, Maruyama T (2000) Diversity of dinoflagellate symbionts (Zooxanthellae) in a host individual. Mar Ecol Prog Ser 195:93-100

Cienkowski L (1871) Über Schwarmer-Bildung bei Radiolarien. Archiv für Mikroskopische Anatomie 7:372-381

Decelle J, Suzuki N, Mahé F, de Vargas C, Not F (2012) Molecular phylogeny and morphological evolution of the Acantharia (Radiolaria) Protist 163:435-450

Decelle J et al - An original mode of symbiosis in open ocean plankton. In revision

de Bary, AH (1878) Vortrag: Uber Symbiose. Tagblatt der 51. Versammlung Deutscher Naturforscher und Aerzte in Cassel. Baier \& Lewalter, Kassel, pp. 121-126

de Vargas C, Bonzon M, Rees NW, Pawlowski J, Zaninetti L (2002) A molecular approach to biodiversity and biogeography in the planktonic foraminifer Globigerinella siphonifera (d'Orbigny). Mar Micropaleontol 45:101-116

Douglas AE (1998) Evolution of mutualistic symbiosis without vertical transmission in symbiosis. Heredity 81:599-603

Douglas AE, Smith DC (1989) Are endosymbioses mutualistic? TREE $4: 350-352$

Edvardsen B et al. (2011) Ribosomal DNA phylogenies and a morphological revision provide the basis for a revised taxonomy of the Prymnesiales (Haptophyta). Eur J Phycol 46:202-228 
Edvardsen B, Imai I (2006) The ecology of harmful flagellates within Prymnesiophyceae and Raphidophyceae. In Ecology of Harmful Algae, Ecological Studies, Vol. 189 (Granéli, E. \& Turner, J.T., editors), 67-79. Springer, Berlin

Faber WW Jr, Anderson OR, Lindsey JL, Caron DA (1988) Algal-foraminiferal symbiosis in the planktonic foraminifer Globigerinella aequilateralis: I. Occurrence and stability of two mutually exclusive chrysophyte endosymbionts and their ultrastructure. J Foram Res 18:334-343

Febvre J, Febvre-Chevalier C (1979) Ultrastructural study of zooxanthellae of three species of Acantharia (Protozoa: Actinopoda), with details of their taxonomic position in the prymnesiales (prymnesiophyceae, Hibberd, 1976). J Mar Biol Ass UK 59:215-226

Foster RA, Collier JL, Carpenter EJ (2006a) Reverse transcription PCR amplification of cyanobacterial symbiont $16 \mathrm{~S}$ rRNA sequences from single non-photosynthetic eukaryotic marine planktonic host cells. J Phycol 42:243-250

Foster RA, Carpenter EJ, Bergman B (2006b) Unicellular cyanobionts in open ocean dinoflagellates, radiolarians, and tintinnids: ultrastructural characterization and immunolocalization of phycoerythrin and nitrogenase. J Phycol 42:453-463

Franck SA (1996) Host symbiont conflict over the mixing of symbiotic lineages. Proc R Soc Lond B 263:339-344

Gast RJ, Caron DA (2001) Photosymbiotic associations in planktonic foraminifera and radiolaria. Hydrobiologia 461:1-7

Gast RJ, Caron DA (1996) Molecular phylogeny of symbiotic dinoflagellates from planktonic foraminifera and radiolaria. Mol Biol Evol 13:1192-1197

Gottschling M et al (2005) A molecular phylogeny of Scrippsiella sensu lato (Calciodinellaceae, Dinophyta) with interpretations on morphology and distribution. Eur J Phycol 40:207-220

Gouy M, Guindon S, Gascuel O (2010) SeaView version 4: a multiplatform graphical user interface for sequence alignment and phylogenetic tree building. Mol Biol Evol 27(2):221-224

Guillou L et al (2008) Widespread occurrence and genetic diversity of marine parasitoids belonging to syndiniales (Alveolata). Env Microbiol 10:3349-3365

Haeckel E (1888) Die Radiolarien (Rhizopoda Radiolaria). Eine Monographie, Dritter Teil, Die Acantharien oder Actinopyleen-Radiolarien. Verlag von Georg Reimer, Berlin, pp 33

Hollande A, Carré D (1974) Les xanthelles des radiolaires sphaerocollides, des acanthaires et de Velella velella: infrastructure - cytochimie - taxonomie. Protistologica 4:573-601 
Keller MD, Selvin RC, Claus W, Guillard RRL (1987) Media for the culture of oceanic ultraphytoplankton. J Phycol 23:633-638

LaJeunesse TC (2001) Investigating the biodiversity, ecology, and phylogeny of endosymbiotic dinoflagellates in the genus Symbiodinium using the ITS region: in search of a "species" level marker. J Phycol 37:866-880

Lee JJ, Correia M (2005) Endosymbiotic diatoms from previously unsampled habitats. Symbiosis 38:251-260

Litaker RW et al (2002) Seasonal niche strategy of the bloom-forming dinoflagellate Heterocapsa triquetra. Mar Ecol Prog Ser 232:45-62

Liu $\mathrm{H}$ et al (2009) Extreme diversity in noncalcifying haptophytes explains a major pigment paradox in open oceans. PNAS 106:12803-12808

McDonald SM, Sarno D, Scanlan DJ, Zingone, A (2007) Genetic diversity of eukaryotic ultraphytoplankton in the Gulf of Naples during an annual cycle. Aquat Microb Ecol 50:75-89

Michaels AF (1988) Vertical distribution and abundance of Acantharia and their symbionts. Marine Biology 97:559-569

Michaels AF, Caron DA, Swanberg NR, Howse FA, Michaels CM (1995) Planktonic sarcodines (acantharia, radiolaria, foraminifera) in surface waters near Bermuda - abundance, biomass and vertical flux. J Plankton Res 17:131-163

Muscatine L, Falkowski PG, Porter JW, Dubinsky Z (1984) Fate of photosynthetic fixed carbon in light- and shade- adapted colonies of the symbiotic coral Stylophora pistillata. Proc R Soc Lond Ser B 222:181-202

Pochon X, Montoya-Burgos JI, Stadelmann B, Pawlowski J (2006) Molecular phylogeny, evolutionary rates, and divergence timing of the symbiotic dinoflagellate genus Symbiodinium. Mol Phylogenet Evol 38:20-30

Saldarriaga JF, Taylor FJR, Cavalier-Smith T, Menden-Deuer S, Keeling PJ (2004) Molecular data and the evolutionary history of dinoflagellates. Eur J Protist 40:85-111

Schewiakoff WT (1926) The Acantharia. Fauna e Flora del Golfo di Napoli 37:1-755

Shaked Y, de Vargas C (2006) Pelagic photosymbiosis: rDNA assessment of diversity and evolution of dinoflagellate symbionts and planktonic foraminiferal hosts. Mar Ecol Prog Ser 325:59-71

Siano R et al (2011) Distribution and host diversity of Amoebophryidae parasites across oligotrophic waters of the Mediterranean Sea. Biogeosciences 8:267-268 
Siano R, Montresor M, Probert I, Not F, de Vargas C (2010) Pelagodinium gen. nov and P-béii comb. nov., a dinoflagellate symbiont of planktonic Foraminifera. Protist 161:385-399

Spero HJ (1987) Symbiosis in the planktonic foraminifer, Orbulina universa, and the isolation of its symbiotic dinoflagellate, Gymnodinium béii sp. nov. J Phycol 23:307-317

Stern et al (2012) The ribosomal internal transcribed spacer (ITS) as a candidate dinoflagellate barcode marker. PLoS ONE 7(8): e42780. doi:10.1371/journal.pone.0042780

Stoecker DK, Gustafson DE, Verity PG (1996) Micro- and mesoprotozooplankton at $140^{\circ} \mathrm{W}$ in the equatorial Pacific: heterotrophs and micotrophs. Aquat Microb Ecol 10:273-282

Swanberg NR, Caron DA (1991) Patterns of feeding in epipelagic oceanic plankton. J Plankton Res 13:287-312

Tamura K et al (2011) MEGA5: Molecular Evolutionary Genetics Analysis using Maximum Likelihood, Evolutionary Distance, and Maximum Parsimony Methods. Mol Biol Evol 28:27312739

Tillman U, Elbrächter M, Krock B, John U, Cembella A (2009) Azadinium spinosum gen. et sp. nov. (Dinophyceae) identified as a primary producer of azaspiracid toxins. Eur J Phycol 44:6379

Wooldridge SA (2010) Is the coral-algae symbiosis really "mutually beneficial" for the partners? Bioessays 32:615-625

Yellowlees D, Rees TAV, Leggat W (2008) Metabolic interactions between algal symbionts and invertebrates hosts. Plant Cell Environ 31:679-694

Yuasa T, Horiguchi T, Mayama S, Matsuoka A, Takahashi O (2012) Ultrastructural and molecular characterization of cyanobacterial symbionts in Dictyocoryne profunda (polycystine radiolaria). Symbiosis DOI 10.1007/s13199-012-0174-2

Zwirglmaier K et al (2008) Global phylogeography of marine Synechococcus and Prochlorococcus reveals a distinct partitioning of lineages among oceanic biomes. Env Microbiol 10(1):147-161 
Fig. 1 Microscope observations of the host acantharian species Acanthochiasma sp. that harbors microalgae of different sizes and shapes (e.g. small gymnoid cells and large round cells) in its endoplasm, as indicated by the black arrows in C. The insets of A and D highlight the red autofluorescence of chlorophyll-containing microalgae where different cell sizes are also observed. In $\mathrm{C}$ and $\mathrm{D}$, Acanthochiasma sp. triggers encystment upon intense manipulation under the microscope

Fig. 2 18S rDNA phylogeny of dinoflagellates including sequences of symbiotic microalgae of different host taxa (blue) and microalgae associated with the host Acanthochiasma sp. (bold red font). The phylogenetic tree was built by a Maximum Likelihood (ML) analysis based on 1534 aligned positions, 86 taxa and the GTR+G+I model. The tree was rooted with 3 sequences of Alexandrium sp. from the order Gonyaulacales as the outgroup. ML bootstrap values $>50 \%$ are shown at nodes (100 pseudo-replicates)

Fig. 3 ITS rDNA phylogeny of the dinoflagellate order Peridiniales including sequences of microalgae associated with the host Acanthochiasma sp. (bold red font). The phylogenetic tree was built by a Maximum Likelihood (ML) analysis based on 731 aligned positions, 50 taxa and the GTR $+\mathrm{G}$ model. The tree was rooted with 4 sequences belonging to the sister order Sussiales as an outgroup. ML bootstrap values $>50 \%$ are shown at nodes (100 pseudo-replicates)

Fig. 4 ITS rDNA phylogeny of the dinoflagellate order Suessiales including sequences of symbiotic microalgae of different host taxa (blue) and microalgae associated with the host Acanthochiasma sp. (bold red font). The phylogenetic tree was built by a Maximum Likelihood (ML) analysis based on 813 aligned positions, 39 taxa and the HKY $+\mathrm{G}$ model. The tree was rooted with 3 sequences as outgroup of Heterocapsa sp. belonging to the sister order Peridiniales. ML bootstrap values $>50 \%$. are shown at nodes (100 pseudo-replicates). Subclades P1a, P1b, P2a and P2b of the species Pelagodinium béii are labeled according to Shaked and de Vargas (2006)

Fig. 5 18S rDNA phylogeny of haptophytes including the sequences of microalgae associated with the host Acanthochiasma sp. (bold red font). The phylogenetic tree was built by a Maximum Likelihood (ML) analysis based on 717 aligned positions, 47 taxa and the $\mathrm{K} 2+\mathrm{G}$ model. The tree was rooted with 4 sequences of Phaeocystis sp. as an outgroup. ML bootstrap values $>50 \%$ are shown at nodes (100 pseudo-replicates). Clades B1 and B2 are labeled according to Edvardsen et al. (2011). In clade B2, 3 sequences of symbiotic microalgae (highlighted in blue) obtained from planktonic Foraminifera in Gast et al (2000) are shown 


\section{Tables legends}

Table 1 Information about the twelve host cells of Acanthochiasma sp. collected in September 2010 and 2011, including the genetic identity of their intracellular microalgae 
Figure2

Click here to download high resolution image

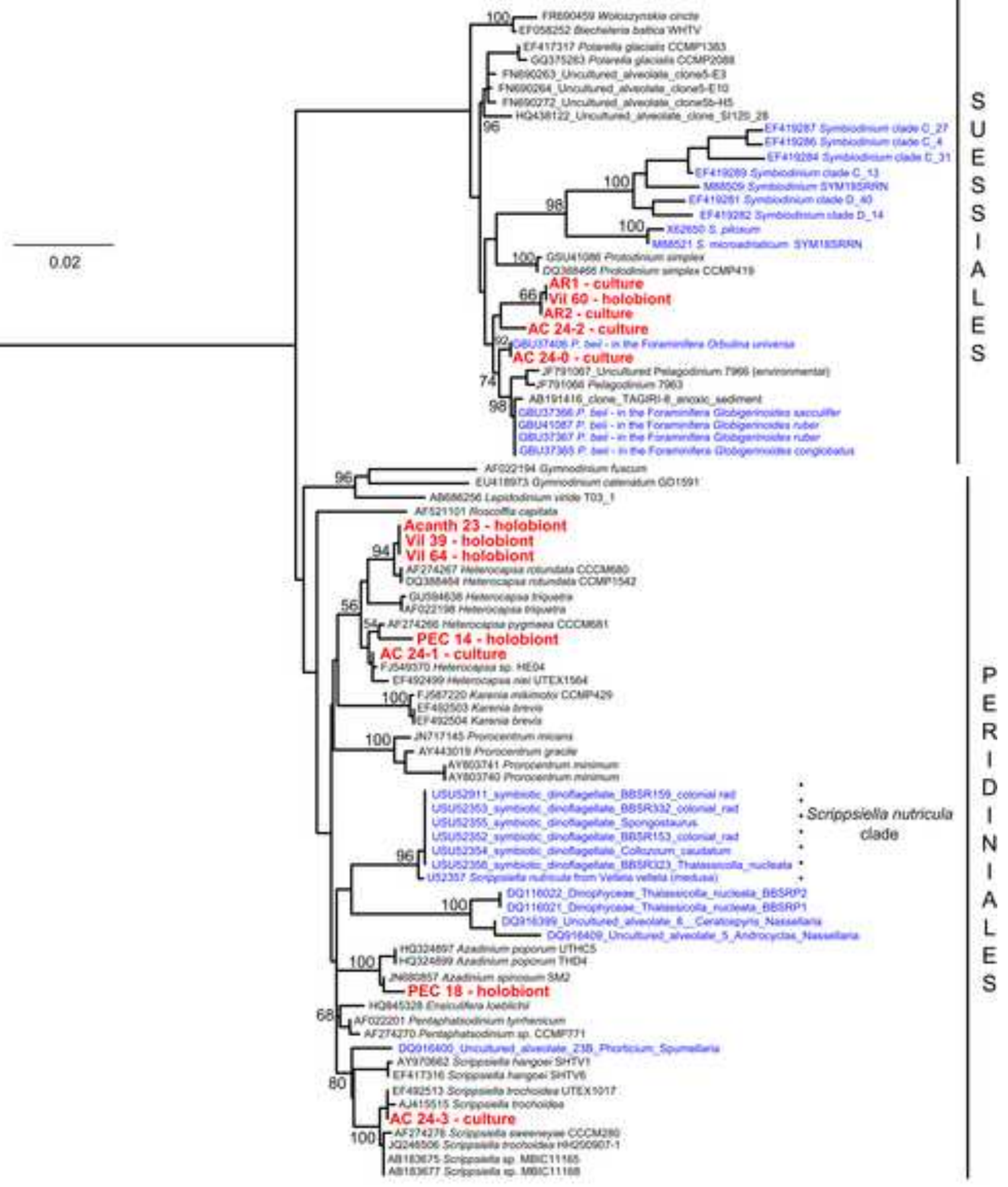

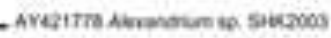




\section{Figure3}

Click here to download high resolution image

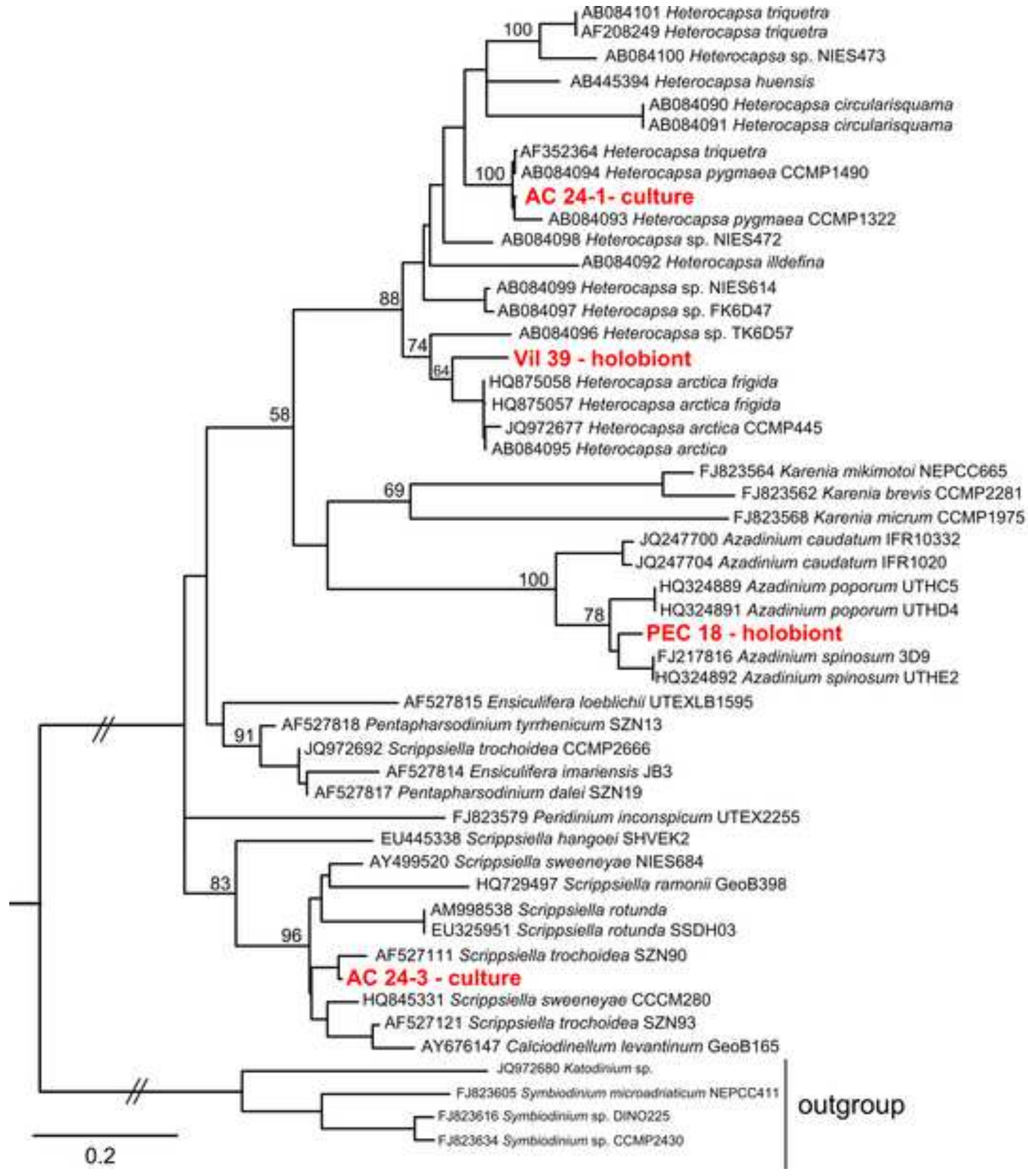




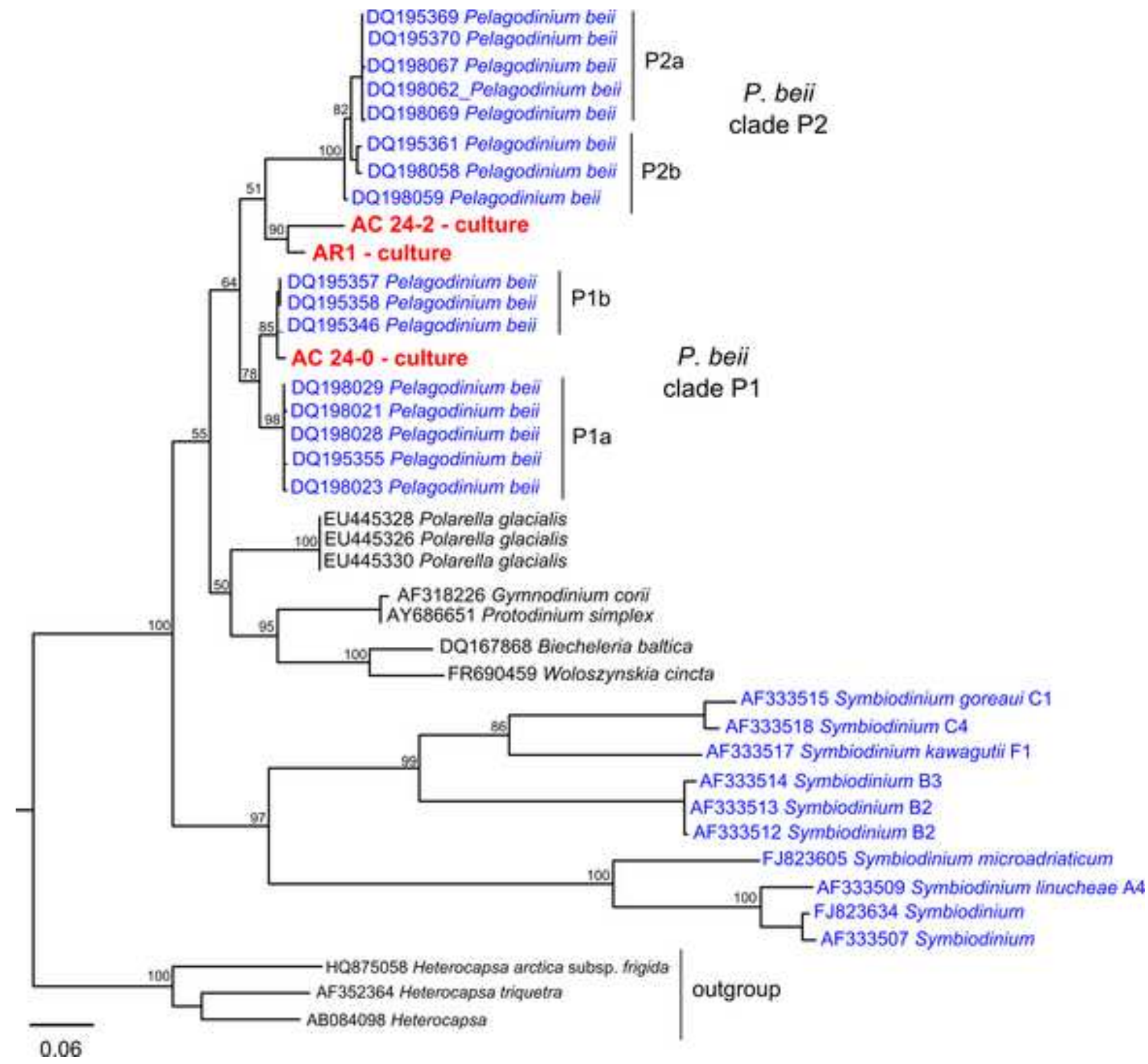


Click here to download high resolution image

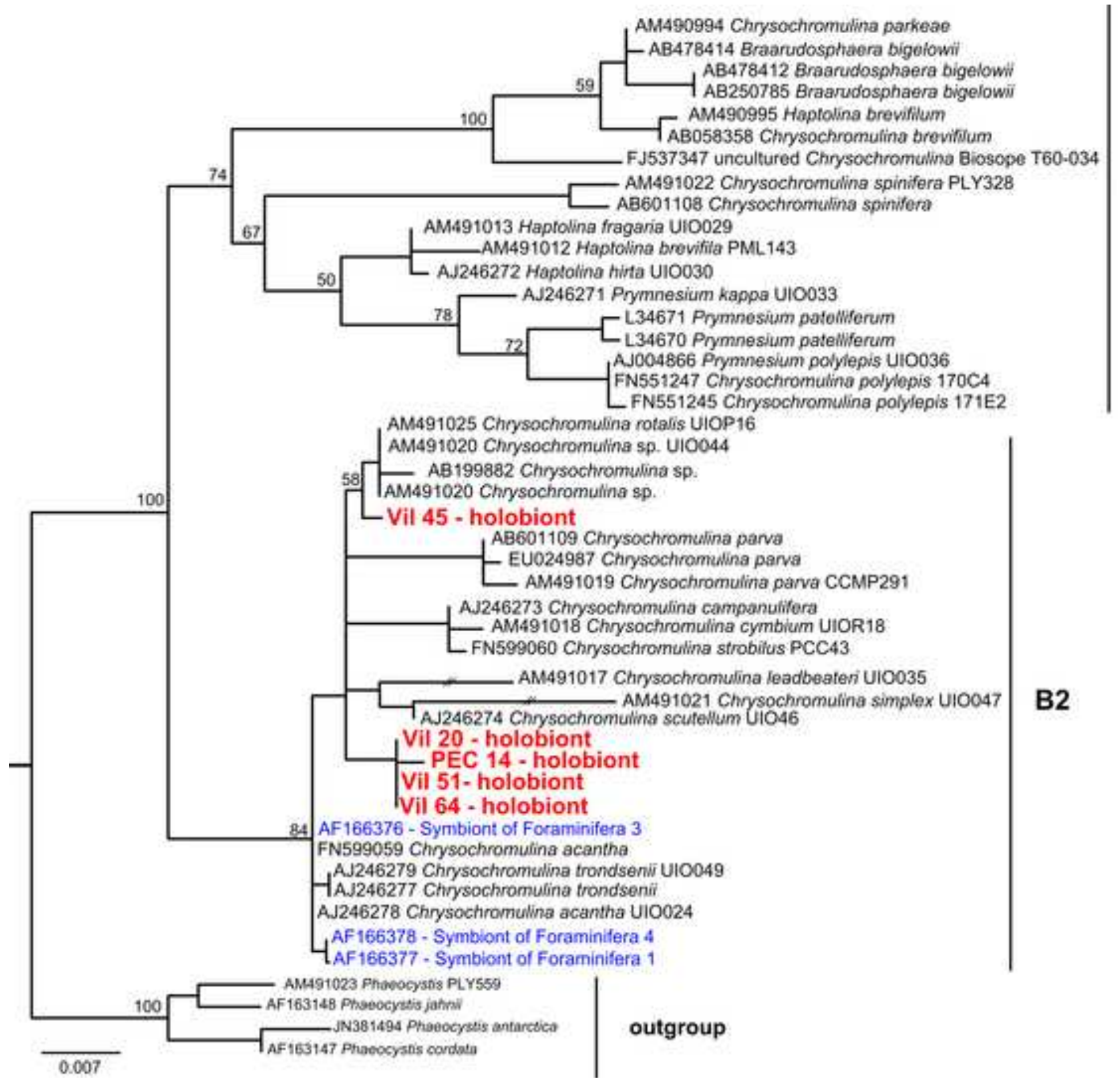




\begin{tabular}{|c|c|c|c|c|c|c|c|c|c|}
\hline Host & $\begin{array}{l}\text { Methods } \\
\text { ID }\end{array}$ & $\begin{array}{c}\text { Collection } \\
\text { Date }\end{array}$ & $\begin{array}{l}\text { Host } \\
185\end{array}$ & $\begin{array}{l}\text { Host } \\
\text { ITS }\end{array}$ & $\begin{array}{c}\text { Chrysochromulina } \\
\text { clade B2 }\end{array}$ & P. beii & $\begin{array}{c}\text { Heterocapsa } \\
\text { sp. }\end{array}$ & $\begin{array}{c}\text { Scrippsiella } \\
\text { sp. }\end{array}$ & $\begin{array}{c}\text { Azadinium } \\
\text { sp. }\end{array}$ \\
\hline Vil20 & holobiont & 2010 & identical & identical & $\mathrm{x}$ & & & & \\
\hline Vil45 & holobiont & 2010 & identical & identical & $x$ & & & & \\
\hline Vil51 & holobiont & 2010 & identical & identical & $x$ & & & & \\
\hline Vil64 & holobiont & 2010 & identical & & $x$ & & $\mathrm{x}$ & & \\
\hline PEC14 & holobiont & 2011 & identical & & $x$ & & $x$ & & \\
\hline Vil39 & holobiont & 2010 & identical & & & & $x$ & & \\
\hline Acanth23 & holobiont & 2011 & |dentical & & & & $x$ & & \\
\hline Vil60 & holobiont & 2010 & & & & $x$ & & & \\
\hline PEC18 & holobiont & 2011 & identical & & & & & & $x$ \\
\hline $\mathrm{AC} 24$ & cultures & 2011 & & & & $x x$ & $x$ & $x$ & \\
\hline AR1 & cultures & 2011 & & & & $x$ & & & \\
\hline AR2 & cultures & 2011 & & & & $\mathrm{x}$ & & & \\
\hline
\end{tabular}

